\title{
A Four-billion-year Story: The Making of India
}

Barry Wood

University of Houston

Correspondence | bwood@uh.edu

Citation | Wood, Barry. 2019. "A Four-billion-year Story: The Making of India." Journal of Big History, IV (1): 49-66.. http:// dx.doi.org/10.22339/jbh.v4i1.419o.

DOI | http://dx.doi.org/10.22339/jbh.v4i1.419o

\begin{abstract}
Sixty-five years ago, A. L. Basham highlighted the making of India in his book, The Wonder that was India (1954). It acknowledged human presence 100,000 years ago; the dawn of agriculture around 10,000 BC; the rise of the first villages; ancient goddess figurines; the Indus Valley civilizations; and the great discovery by Sir William Jones of India's languages linked to the languages of Europe. Basham also emphasized the importance of the Himalayas and the great fertile plains watered by the multiple tributaries of the Ganges - the spiritual and cultural center of ancient India. With intensely economic and political perspectives today, we are likely to adopt the narrower focus of Ranbir Vohra's The Making of India: A Political History (2013), which leads us through British colonialism to India's emergence as an independent democracy of over a billion people. In recent years a broader perspective has emerged that extends far beyond the beginnings of Indian civilization or even beyond the first nomadic migrants. Discoveries of geology, biology, and paleontology define the making of India as a vast narrative, the creation of a stage with ancient roots upon which modern humans have only recently commenced their walk-on drama. This perspective impels us to think historically, sequentially, and diachronically rather than topically or synchronically. India turns out to be a dramatic example of continental migration culminating in a collision that has shaped Asia far beyond India's borders. The making of India emerges as a dynamic, moving sequence where the most ancient planetary and biological events are seen as contingencies of the present world and human existence. This perspective is more than history; it is big history; more than narrative, it is a grand narrative.
\end{abstract}

\section{Introduction}

The central discovery of twentieth -century geology in India and elsewhere has been a recognition of slow but constant planetary change that put an end to the notion of a world as fixed and finished. "Change," however, is an abstract term without precise parameters. This was clear when geologist James Hutton (1726-1797) put forth his "theory of the Earth." Hutton saw a continual process of mountain erosion, settlement of water-borne erosional materials on ocean bottoms, their hardening into fossil-laden sedimentary rock, and subsequent upthrust of sea bottom that formed new mountains. This was change-a rock cyclethat by definition must have occurred everywhere that mountains tower and rivers flow to the sea. Hutton's conclu- sion was that this cycle went on "without end"; he could not define a beginning. Hutton was the first to recognize what we call "deep time" (Wood 2019a). To this, the eminent geologist, Charles Lyell (18301832), added regional specificity. From his study of geological change at Mount Etna, the Joggins Fossil Cliffs on the Canadian coast, and the Grand Canyon, Lyell documented change at specific sites: ninety eruptions on Etna, millions of years of fossiliferous layers at Joggins, and mile-deep sedimentary layers at the Grand Canyon. Their crucial recognition was that the Earth had an immeasurably long history; such vast changes could not have occurred within any restricted time frame. To this insight, Charles Darwin (1859) added a biological dimension: fossilif- erous rocks revealed an equally immeasurable sequence of life forms from primitive to modern with many dead-end pathways to extinction. As the nineteenth century came to an end, these various kinds of change had provided multiple perspectives, but they hung together with impenetrable complexity.

A new view of change began with Alfred Wegener's theory of a supercontinent which he called Pangea (All Earth) which he sketched in his book, The Origin of Continents and Oceans (1912), that went through several editions until 1929. His evidence included the obvious "fit" of continents on each side of the Atlantic Ocean and samespecies megafauna fossils occurring on landmasses separated by thousands of miles of ocean. His solution was the 
theory of a supercontinent he called Pangea (All Earth) where all the landmasses of the planet were once joined (Illustration No. 1).

Wegener's theory of an ancient continent he called Pangea along with drifting continents, which accounted for the widely separate locations of lands once joined, became "a theory that most academics quickly branded eccentric, preposterous, and improbable ... a classic example of wild, overreaching supposition" (Ballard 200o, 117-119). His theory thus made little headway and was largely ignored for decades. How continents supposedly rooted into the rocky surface of the Earth could possibly move challenged the geological imagination. But oceanbottom exploration during IGY, the International Geophysical Year (19571958 ), led to the discovery of midocean undersea mountain ridges, seafloor spreading (Dietz 1961), a systematic creation of seafloor, and thus a "history of ocean basins" (Hess 1962). The evidence confirmed that continents did move, and a rapid assessment of the evidence led to the master theory of modern geology: "plate tectonics" (Takeuchi 1970; Sullivan 1974). Within two decades, instrumentation capable of measuring continental movement had developed. This was refined enough to show that North and South America were moving away from Europe and Africa at approximately one centimeter per year. Wegener's continental drift was no longer a theory; it was a fact.

Verification that continents moved brought astonishment and it remains astonishing for anyone first encountering it. This, however, can momentarily conceal its significance. The various kinds of "change" Hutton, Lyell, and Darwin had recognized lacked direction. Lyell's observations confirmed local change; Hutton's flow of erosional material to form ocean bottoms and their subsequent upthrust to form mountains was vertical change. But the movement of continents involved change "that played itself out far more in the horizontal than in the vertical direction" (Ballard 2000, 125). Moreover, this was directional change: continents were mov- ing, but this movement could be tracked backward in time. One could see not only where continents were headed, but where they had been. Geological change suddenly acquired pattern and structure. It signified a history.

Once the reality of Wegener's Pangea was established, geologists began the complex task of working out the earlier history of the planet. One approach was to trace out the precise configuration of Pangea by exploring continental shelves and continuities between geographical features on opposite sides of the oceans. Discoveries included identical chemical signatures on facing coastline rock outcrops originally together during the Pangea era. Working out details of Pangean configuration was soon extended to the daunting task of tracing the history of plate movement before the assembly of Pangea. Bit by bit, clues led to evidence and the pieces of narrative stretching over billions of years began to emerge. As the search went forward, outcrops of very ancient rocks were located and dated. Rocks that indicated formation 3.5 billion ( 3500 million) years ago were found in Africa, Australia, Greenland, and Northern Canada. Gradually their origins and movements were traced to construct a chronology of plate tectonic events. The ancient narratives of Earth's continents are all of great interest, but the making of India is unique.

\section{Craton}

What geologists have learned is that India is the most dramatic example of continental migration, initially moving faster than any other terrane and colliding so forcefully that it altered the geography of Asia far beyond the site of the original collision.

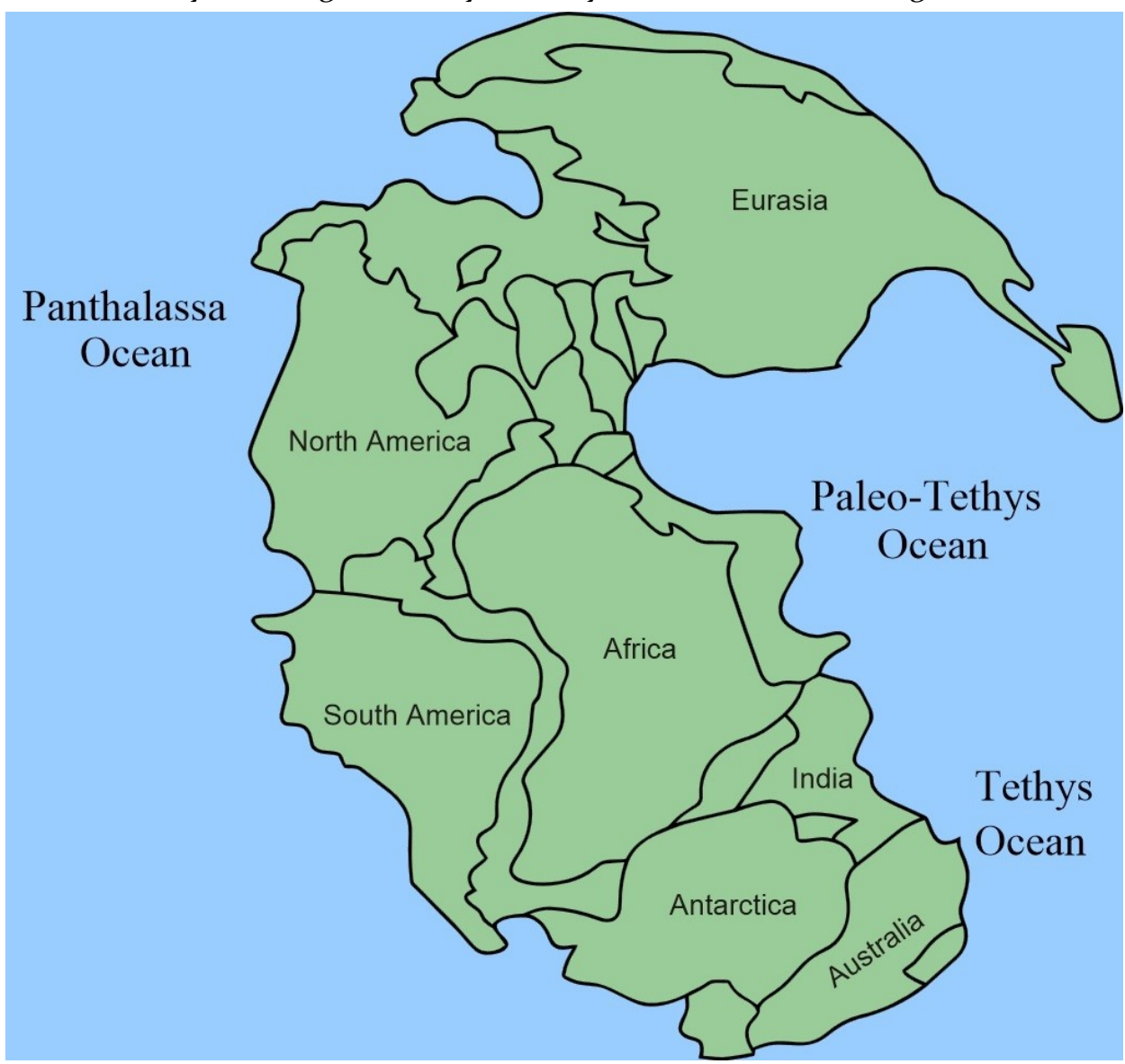

Illustration 1: Pangea. Alfred Wegener proposed an ancient supercontinent called Pangea to account for similar megafauna fossils on continents separated by thousands of miles of ocean. In The Origin of Continents and Oceans (1912) he provided sketches of how Pangea might have been configured. His theory of "continental drift" was necessary to account for the locations of today's continents. Source: commons@wikimedia.com. 
In the process, India has rafted a history of ancient cratons and the rise of life hundreds of miles from where these originated, relocating this landmass where it became a coastal route traversed by early humans and a place congenial for others who decided to stay and settle.

The prehistoric history of India began to emerge around the midtwentieth century. In his early work on cratons the oldest foundational crustal underlying Peninsular India, B. Rama Rao $(1945,16)$ remarked on Archaean rocks in general that they "constitute a complex of highly crumpled crystalline schists and gneisses massed into a confused jumble." These are metamorphic rocks formed from earlier sedimentary or igneous rocks. Rao's description of a "jumble" refers to gneisses formed at high temperatures mixed with schist formed at lower temperatures, a combination not easy to explain. From their conglomerate composition, Rao concluded that the oldest Archean rocks were formed from preexisting rocks that had eroded and been subject to subsequent igneous and metamorphic processes. Rao's explorations identified dozens of components of these cratonic rocks that were laced with recrystallized sediments rich with magnesium and iron. Half a century later, University of North Carolina professor of geology, John J. Rogers (1993), established an age of 3.1 billion (3100 million) years for cratonic rocks, not only in India but also in West Australia and East Africa. The predecessor rocks suggested by Rao may thus have formed as much as 600 to 900 million years earlier, toward the end of the Hadean Era. This estimate pushed the earliest chapter of the making of India as far back as four billion years ago.

From similarities between rocks from widely separated landmasses, Rogers surmised that the cratonic foundations must have formed together in the Archean Era after which they remained crowded together for more than 3 billion years until they drifted apart during the breakup of Pangea. Rogers provided the name $U r$ (German: Motherland) for the earliest stage of these conjoined cratons which he inferred had made up an earlier supercontinent. Further explorations of continental movement soon opened up further reaches of prehistory: intermediate cratonic conjunctions were recognized, and a series of supercontinents were understood as assembling and breaking up between Ur and Pangea.

In a boldly titled article, "History of Continents in the Last Three Billion Years," which expanded his observations from India, Rogers (1996), laid the groundwork for an extended geological narrative. Some of his conjectures have since been modified, but his emphasis on a chronological sequence of events has become a foundation for diachronic geology. Piecing together what has been observed about other cratonic assemblies, we can work out a supercontinent timetable: 2.5 billion-year-old Laurentia, 2billion-year-old Baltica, and most of northern Asia collided around 1.5 billion years ago to form Laurasia; then a billion years ago these collided with $U r$ and Atlantica to form Rodinia, the predecessor of Pangea. Rodinia lasted about 300 million years, and then fragmented around 700 million years ago. Laurasia remained somewhat intact while a great southern continent was assembled from most of the southern hemisphere cratons. Once this and Laurasia drifted together around half a billion years ago, the familiar supercontinent of Pangea was formed. Through these various combinings and separations, the Indian basement cratons remained intact.

Rogers' initial speculations about $\mathrm{Ur}$ and subsequent supercontinents began with the rocks of the Dharwar craton of southern India where less overlying sediment has left outcrops of the underlying craton exposed. The crustal foundation of India includes four other cratons that were sutured together during the late Pre-Cambrian Era: from these earlier dates have emerged. Basu et al. (1981) have dated remnant Archaean granitic rocks from the Singbhum craton in northeastern India at 3.8 billion (3800 million) years old. In light of Rao's intuition that these preserve components from earlier rocks, the first chapter of the mak- ing of India must begin somewhat earlier. The rocks of all five cratonic outcrops display a suite of igneous-origin metamorphic gneisses and schists that appear to have formed around 500 million years after Earth formation 4.5 billion years ago; that is, around four billion years BP. Whatever rocks hardened toward the end of the Hadean were then subject to subsequent erosion and breakdown. Subsequent continental cratons worldwide are thus conglomerates of erosional components from these pre-existing rocks that finally hardened and survived without further meltdown. Today they make up the basement foundations of continental cratons and the Indian Shield.

Plate tectonics was understood as a phenomenon explaining hitherto unexplained geological events. Once the fact of seafloor spreading and subduction was recognized, mechanisms for earthquakes and volcanoes came into focus. But the driving force of plate tectonics was only vaguely understood. Now we infer that continental movement most likely originates with plumes of superheated lava deep in the Earth which rise toward the surface, split, spread, and flow off in different directions. This sets up convection currents near the surface of the Earth's mantle immediately beneath the crust which is of lighter density and thus "floats" on the heavier mantle. Crust thickness varies: under the Indian Ocean, it averages 100 kilometers (62 miles) in contrast with the crust under the cratons of Africa, Antarctica, and Australia which runs to 180 kilometers (110 miles) in thickness (Kumar et al. 2007). Continents supported by huge crustal slabs ride on mantle currents like rafts on a river. Here we see the fundamentals of the entire theory of plate tectonics. In addition, some plumatic material finds its way into cracks and crevices in the Earth's crust as lava intrusions which slowly force crustal plates apart, thus aiding their convectional flow.

Through all of these breakups and reassembles, the India cluster of cratonic fragments seem to have remained intact. Unlike the African craton, which was located at the center 
of supercontinents and thus surrounded by other cratons, India generally occupied the periphery. Thus, when Pangea broke up-eventually birthing the seven continents we know today-India was positioned for a separate departure, a migration north from Pangea at what in geological terms was breakneck speed, and an eventual collision with Asia. Calculations indicate that India may have commenced its travels at 20 centimeters (12 inches) per year (Kumar et al. 2007). But as Jonathan Aitchison et al. (2007) have shown, its movement varied over its 100-million-year journey north. Moreover, even though it collided with Asia 40 million years ago, it is still moving at 5 centimeters (3 inches) annually, the result being a continuous crushing and compression of the South Asian landmass and the still-rising peaks of the highest mountains in the world, the Himalayas.

\section{Life}

While geological changes were occurring, a parallel narrative was unfolding. The evidence in India consists of stromatolite fossils marking the advent of bacterial colonies more than 3 billion years ago (Sharma 2008). But the broader story has several earlier chapters; the first is planktonic and microscopic. Evidence for the origin of life, or abiogenesis, is found in the oldest cratonic rocks on most of today's continents. Matthew Dodd et al. (2017) have found microfossil evidence of primitive bacterial life dating to the early Archean Era in the Canadian province of Quebec; undoubtedly, these were not unlike today's plankton which make up over ninety percent of Earth's present biomass (Sardet 2015). These Canadian microfossils were found within precipitates from hydrothermal vents which occur on ocean floors and date from 3.77 to 4.28 billion years BP. Hydrothermal vents or "black smokers" several kilometers below the ocean surface which occur along mid-ocean ridges provide an environment isolated from solar radiation, meteoric bombardment, and the intense heat at the Earth's surface during the Hadean Era. Robert D. Ballard (2000), who was among the first to explore mid-ocean ridges and black smokers has provided a riveting account of their discovery along with the varied environments occupied by these "chemosynthesizing organisms," that are powered by the constant flow of metals, gases, and sulphur compounds spewing out of the vents.

As the ocean surface cooled following the Hadean Era, new forms of solar-tolerant plankton evolved: autotrophic bacteria capable of separating hydrogen from $\mathrm{H}_{2} \mathrm{O}$ and retaining the hydrogen while releasing the oxygen into the atmosphere and harvesting solar energy to create sugars. This photosynthesizing process defines these as ancestral to the entire kingdom of plants. Cyanobacteria that collected in "mats" or "colonies" formed stromatolites-mushroomlike structures several feet high in shallow water where tides brought a continual supply of nutrients. Leis and Stinchcomb (2015) have assembled a gallery of evidence showing that stromatolites were a dominant form of life for two billion years in every part of the world. Examples from Pilbara Rock in Australia date to 3.4 to 3.5 billion years BP (Walter 1983); from South Africa, 3.5 to 3.6 billion years BP (Knoll and Barghoorn 1977). Stephen Jay Gould (1989) remarked that stromatolites were "the highest form of macroscopic complexity" in the Precambrian world 3.5 billion years ago. But around 500 million years ago they waned under competition from other life forms, and they are rare today, though some still thrive in a few remote locations, most notably in Sharks Bay in Western Australia where they are exposed at low tide. In addition, a variety of open-ocean stromatolites are found at Carbia in Western Australia and Exuma Sound in the Bahamas where subtidal currents provide a constant nutrient flow. However, the fossil evidence is ubiquitous, revealing that stromatolites colonized ancient shorelines everywhere and thus were subject to tectonic movement, coastal mountain building, seafloor uplift, and terrane additions to ancient coasts that moved stromatolite fossils far inland and often to high elevations. There are numerous exam- ples from the $510+$ million-year-old Burgess Shale hundreds of miles from the Pacific at an elevation of 8,00o feet in the Canadian Rockies.

In India, Schopf and Prasad (1978) located a conjunction of stromatolites and microfossils dating to 1.4 billion years ago in the Cuddapah Basin of South Central India. A rather spectacular outcrop of stromatolites of similar age was discovered far removed from their original oceanic location in the Uttar Pradesh province of Northern India, now protected in the Salkhan Fossils Park (Leis and Stinchcomb, 6o). Based on geochronology, these may have formed originally around the coastal regions of Atlantica to which the Indian cratons were attached in the Archean Era. But these are not the earliest fossils in India. Geologist Naresh Ghose (Ians 2017) has reported locating microfossils, probably formed during the time of the original Ur supercontinent, dating to more than 2 billion years $\mathrm{BP}$ in the Gwalioer Basin of the Bundelkhand region. Fossil microbiota from 2.4 to 2.6 billion years ago have been located in Precambrian rocks in various locations in India (Lopuchin and Moralev 1973; Lopuchin and Gowda 1983). In all cases these fossils were carried by the India cratons from their places of origin in earlier supercontinents.

Toward the end of the Precambrian Period around 750 million years ago, a new form of marine life appeared that provided a new biological chapter. Multi-celled organisms emerged, probably from cooperative assemblies of planktonic bacteria, eukaryotes, and the like. The earliest were soft-bodied invertebrates resembling jellyfish. Lacking either bones or shells, invertebrates are poorly recorded in the fossil record, though the Burgess Shale of the Canadian Rockies has preserved some (Briggs et al. 1994). During the Cambrian Era (542 to 488 million years ago) the fossil record reveals an astonishing proliferation of species with hard partsbones and shells. This occurred as Laurasia-North America, Europe, and northern Asia-was drifting toward the clumped cratons of southern 
continents: "At this time," writes M. S. Krishnan (1982, 239), "there existed a great Southern Continent or a series of land masses which were connected closely enough to permit the free distribution of terrestrial fauna and flora. This continent, which included India, Australia, South America, Antarctica, South Africa and Madagascar, has been called Gondwanaland." But since wana means "land," Gondwana-land is redundant and so has been officially shortened to "Gondwana" (Illustration 2). The name goes back to the nineteenth century: the geologist Otokar Feistmantel (1876), who was studying fossils in the north central provinces of India, named this region Gondwana after the ancient tribe of Gond who still occupied it.

Shortly after Laurasia collided with Gondwana to form Pangea around 500 million BP, the Cambrian Explosion of proliferating genera and species set in, resulting in a biodiversity of millions of life forms across the supercontinent. Despite the relatively brief duration (50 million years) of the Cambrian Era, 20 to 35 of the major phyla known today emerged. This includes an array of marine phyla, including invertebrate, three-lobed trilobites, with over 50,00o separate species identified. As Riccardo Levi-Setti (2014) illustrates, they have been found in Bohemia, China, Morocco, Newfoundland, North America, Russia, and the United Kingdom; they are also found in the Devonian Era Hunsrück Slate west of the Rhine Valley in western Germany along with numerous other highly evolved invertebrates (Kühl et al. 2012). Among fossils, trilobites have inspired more fossil hunters than any other form of life, with spectacular museum collections in Boston, Cancun, Glasgow, London, New York, Prague, Toronto, and Washington DC. Some, like the Houston Museum of Natural Science, have benefited from donations of superlative private collections (Wessman and Eberle 1999). This proliferating form of exoskeletal life, which evolved eyes long before mammals and primates (Clarkson et al. 2006), dominated the world's oceans for 300 million years.

Cambrian fossils in India from rich fossiliferous beds in Kashmir and the Spiti regions consist primarily of brachiopod valves and trilobites (Krishnan, 217). As we trace the fossil record of India from the Cambrian (544-488 mya) through the Ordovician (488-444 mya), and Silurian (444400 mya), trilobite fossils are plentiful (Sharma 2008), but they decline through the Devonian (400- 359 mya) and Carboniferous (359-300 mya) periods with their extinction complete by the end of the Permian (250 mya). As the Indian record of trilobite fossils gradually decreases, brachiopod valves remain, along with a multitude of shells of many shapes and designsfans, spirals, cones, and pyramids (Krishnan, 217, 224, 229, 233, 297)which continue to modern times.

The supercontinent of Gondwana of which India was a part existed from 550 until approximately 180 million years ago. Chronicling events through vast prehistoric eras of India is almost indistinguishable from narrating the history of Gondwana itself. To appreciate this geological and biological history, we need to adopt a double vision for which Mary White has provided suggestive terminology. Her Flowering of Gondwana focuses on Australia, but her emphasis on a geohistorical term, "Australia-inGondwana" (1990, 34), prompts us to adopt the parallel "India-in Gondwana." Thus evolutionary development and detail belongs not simply to India but to India-in-Gondwana. While the trilobites came and went, thousands of species originated in India-in Gondwana, then continued far beyond the breakup of Gondwana. According to Mora et al. (2011), the approximate number of species worldwide today is 5.5 million land species, 2.2 million

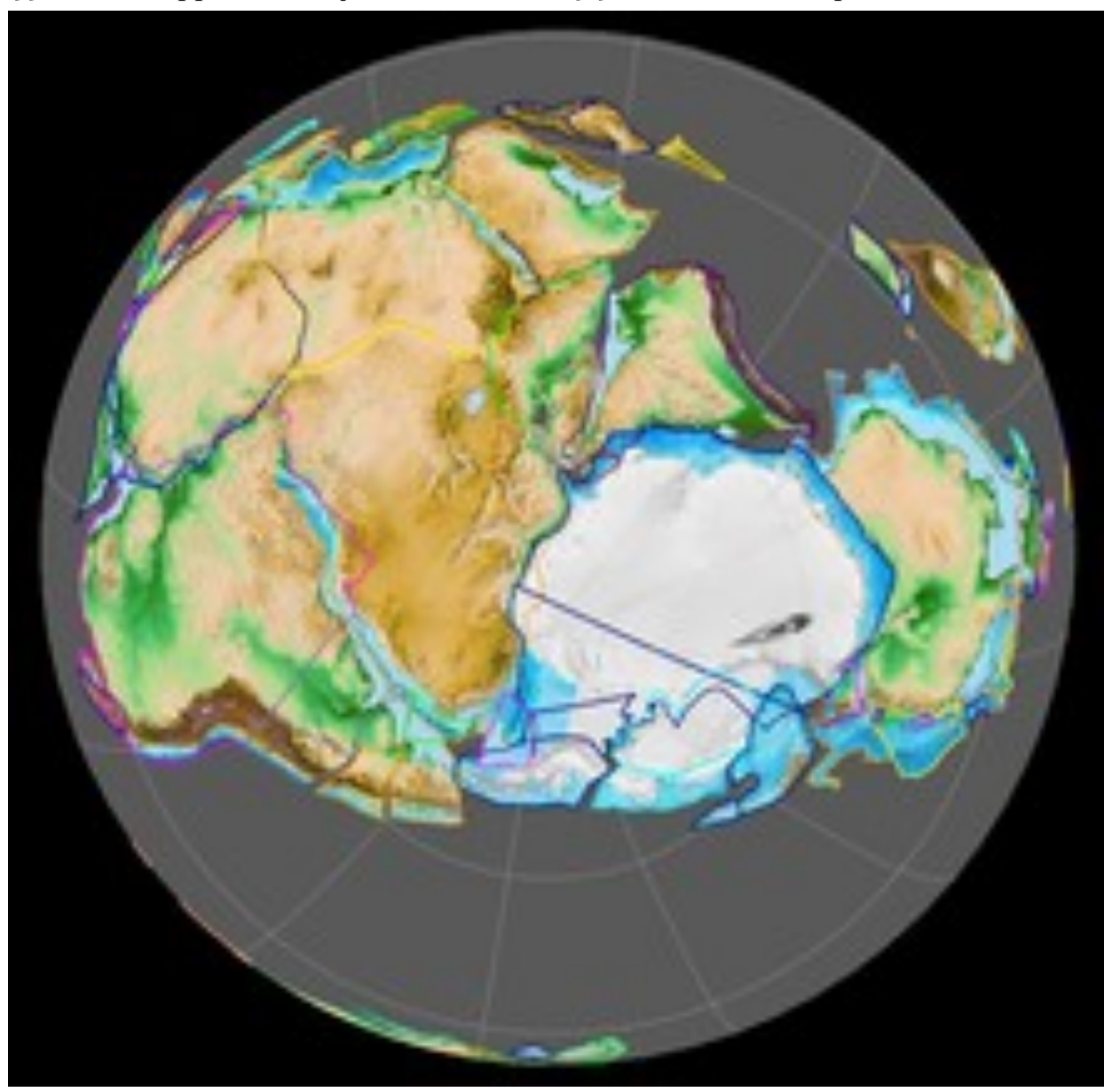

Illustration 2: Gondwana. Before Laurasia (North America and Eurasia) collided with the southern continents and, subsequently, after Laurasia had separated, the gathering of southern continents known as Gondwana persisted as the longest-lasting supercontinent. These southern continents were then clustered with present-day Antarctica. Evidence of glaciation is thus found on all the landmasses that surrounded Antarctica, including southern India. Source: www@wikimedia.com. 
marine species, for a total of $8.7 \mathrm{mil}-$ lion, though some estimates have suggested as many as 100 million. Since most have very ancient histories, the story of life on Gondwana has several additional chapters, for this is where today's faunal and floral species of India originate.

Creatures now considered ancestors of vertebrates-bilaterally organized around a stiffened dorsal rodlike structure known as a notochordhave shown up in Laurasian sites. The tiny fish-like Pikaia in the Burgess Shale of British Columbia first described by Charles Walcott (1911), photographically illustrated by Briggs et al. (1994), and thoroughly analyzed by Morris and Caron (2012) swam the world's oceans twenty million years before true vertebrates. A cephalochordate in southern China called Yunnanozoon, "Animal of Yunnan [province]," appears to be morphologically related to Pikaia, which dates to the mid-Cambrian Era approximately 520 million BP when life existed entirely in the oceans. Since these were without any hard parts, the surprising survival of their fossils is due to the rare way they were preserved: for Pikaia, an undersea mudslide isolated and preserved an entire ecosystem from deterioration of soft body parts (Gould 1989, 69-70).

Since we have no evidence that larger predators had yet evolved, it is likely that these finned Pikaia would soon have numbered in the billions as they spread to every part of the planet. By the time they emerged, three billion years of planktonic marine life had developed not unlike today's: "a bewildering swirl of tiny creatures... more numerous than the stars in the universe ... unseen marine communities of viruses, bacteria, archaea, single-celled eukaryotes, and small planktonic animals" (Armbrust and Palumbi 2015). Plankton form the foundation of a food chain that has nourished marine life throughout Earth's history. The direct vertebrate descendants of Pikaia with major speciation occurring from the MidCambrian through the Silurian and Devonian Eras (520 to 360 million years BP) eventually populated every corner of the planet with approximately half occupying oceans and the other half adapting to freshwater environs. Conway Morris and H. B. Whittington (1979) point to the importance of the Pikaia discovery: "The superb preservation of this Middle Cambrian organism makes it a landmark in the history of the phylum to which all vertebrates, including man, belong." All vertebrates. Since new species of fish are still being discovered, the total number is unknown, though it is certainly in the hundreds of thousands. Based on the exhaustive worldwide FishBase data, fish species of India alone number 250, with subspecies numbering in the hundreds (Froese and Pauly 2018), a proliferation that began during the India-in-Gondwana Era and the supercontinent Pangea. This astonishing diversity of the most basic vertebrate-a precursor for millions of more diverse species brings the significance of these unassuming fossils into the clear light of day. Gould's observation $(1989,322)$ that Pikaia is a "final link in our story of contingency" summarizes how a single species may be ancestral to a whole range of descendants which, in this instance, includes Homo sapiens.

Fish speciation of India-inGondwana Era may be surprising, but this is still an early chapter in the story of life. A momentous shift occurred in the late Silurian and early Devonian Era from 420 to 385 million years BP. The initial movement onto land of floral species began as the necessary precursor for faunal life ashore. It is generally thought that autotrophic green algae, most likely descended from cyanobacteria, were pioneers in occupying land, probably along beaches where tidal nutrients were available, but eventually evolving to draw nutrients directly from rocks and soil. Lichens, which grow in hostile environments worldwide and on rock, provide a suggestive model. The change of the reproduction process from releasing spores in water may have taken millions of years to evolve spore-retention on land, seed reproduction, and utilization of wind to scatter seed-spores. Moisture transport channels within floral stems, along with retention cells and waterproof skins evolved to retain water within vine-like creeping branches, gradually restructuring plant life as "vascular," a description that now applies to all plant life. Meanwhile, specialization of parts like roots in the ground, stiffened stems, and reaction wood to support heavy angled branches were precursors of today's solidly rooted trees, wide-spreading crowns, and tree tops towering hundreds of feet above the ground. Referring to this greening of the Earth, Loren Eiseley $(1957,62)$ called it "the epic march of life from the tidal oozes upward across the raw and unclothed continents."

Once established, forests and jungles became the constant cover of tropical and temperate lands, with thousands of species developing in lowlands, wetlands, and river valleys and hardier species adapting to drylands and upland slopes. Thousands of generations of lowland vegetation lived, matured, fell, and decayed on the forest floor. The resulting deposits of coal establish India as fifth in the world in coal reserves and fourth in the world in coal production, though, as geologist Krishnan (1982, 283) notes, many coal seams in India are "of small extent and thickness and generally of inferior quality" (Krishnan 283), forcing importation of high quality coal for steel production. On a different note, the fossil record includes an India version of what is well known in America-a collection of petrified trees. The National Fossil Wood Park at Santhanur in Perambalur, approximately $35 \mathrm{~km}$ (20 miles) from Puducherry, displays a collection of two hundred petrified trees, dating to the early Cretaceous Era 120 million years BP.

Working in India, the geologist and paleontologist Otokar Feistmantel (1876) provided the first description of Glossopteris, which means "tongue" (Glosso) "fern" (pteris); it referred to a plant with tongueshaped leaves up to a meter in length, a pronounced midrib, and veins linked together appearing like a net. Glossoptera indica and its variations (Gangamopteris, Gondwanidium) are 
widespread in coal deposits in India from the Permian and Carboniferous Eras; seventy species have been identified in India (Chandra and Surange 1979). Feistmantel recognized that the plant group now known as "Glossoptera flora" extended across all of the southern landmasses (Illustration 3).

Feistmantel found this species in a region of northeast India inhabited by the Gond people, and chose to call its extra-India locations "Gondwana," a metaphorical leap that suggests India as the heartland of the earlier supercontinent. Mary White (1990, 34) brings this into focus: "It would seem that the observations of early explorer scientists, who noted the similarities of vegetation in isolated southern lands, started the modern theorizing about moving continents and former supercontinents" - thirty years before Alfred Wegener's suggestion of a southern supercontinent and almost eighty years before its existence was verified. Eventually Feistmantel's "Gondwana" was officially adopted for the Great Southern Continent where these regions once cohered. The importance of glossopteris in India as a key to the Great Southern Supercontinent has been recognized in the 1997 issuance of a stamp (Illustration 4).

Long before the greening of the landscape was complete, its coloration began. Some seventy years ago, Loren Eiseley published a series of essays which he eventually drew together in a book called The Immense Journey (1957). His chapter, "How Flowers Changed the World" is an evocative account of the reproductive innovations of plant life. "The flowers bloomed and bloomed in ever larger and more spectacular varieties. Some were pale unearthly night flowers intended to lure moths in the evening twilight, some among the orchids even took the shape of female spiders in order to attract wandering males, some flamed redly in the light of noon or twinkled modestly in the meadow grasses" $(1957,73)$. Some may hesitate at Eiseley's attribution of intention to flower blossoms; their decorative coloration may be the result of thousands of mutational experiments, most of

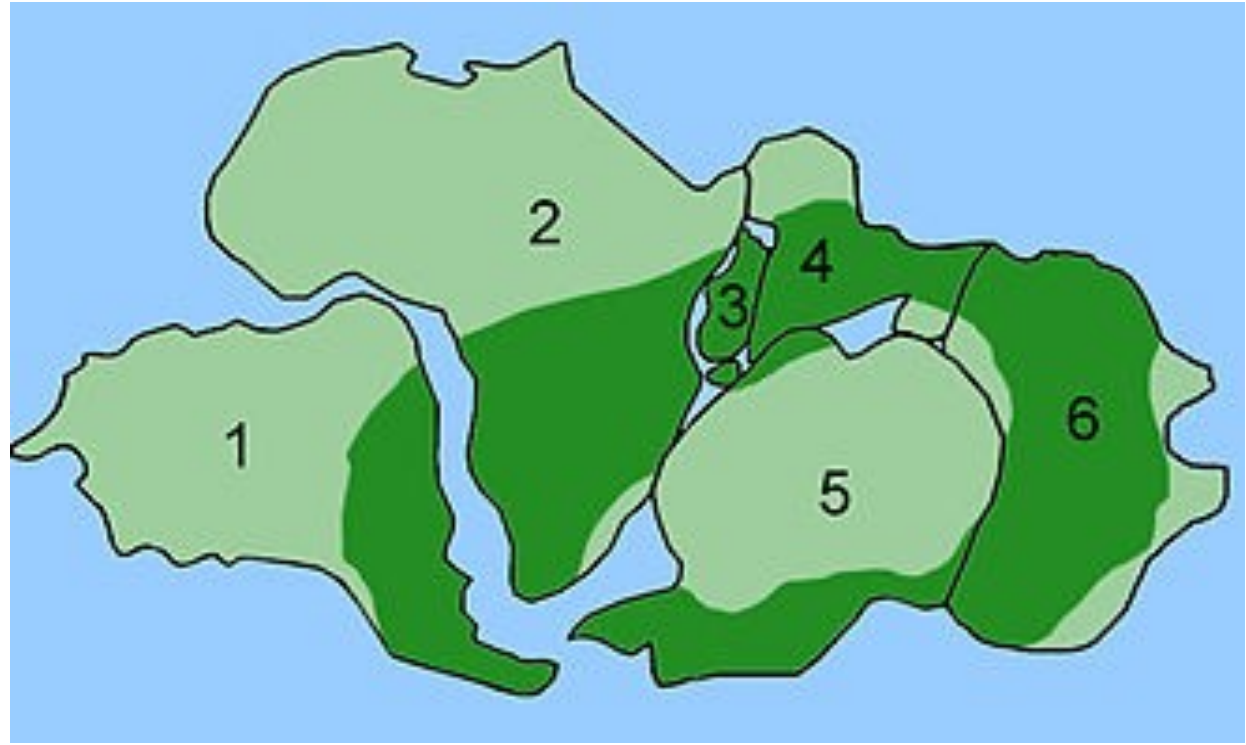

Illustration 3: Glossoptera Range. Glossoptera appeared early in the Permian Era (c. 300 million BP). While Glossoptera was first identified in India, fossil varieties were recognized as common in South America (1), Africa (2), Madagascar (3), India (4) the temperate rim of Antarctica (5), and Australia (6), thus providing evidence for an ancient gathering of landmasses in a supercontinent now known as Gondwana. Glossoptera thrived for 50 million years; most species fell victim to the mass extinction at the end of the Permian (c. 250 BP), with a few survivors evident in India from the early Triassic (Pant and Pant 1987).

them failures, until the most effective variety emerged. Despite remarkable designs that emerge in nature, evolution is a hit-and-miss affair with plenty of loose ends and runny edges. But effective varieties eventually prevailed in the flowering; these included lures and strategies that bound faunal life to floral. No matter how one frames the meandering road to cooperative floralfaunal ecosystems, the flowering plants that produced nectar in order to spread their seeds, cone-seeds that are spread by foraging mammals, and hanging fruit that serve as attractive forms of nutrition-all these provided new sources of food for new species of life. And all these innovations occurred while India was still India-inGondwana.

With the land prepared as a habitat that included thousands of varieties of plant life, vertebrate invasions of land were inevitable. India experienced it as fully as every other part of the supercontinent. The transitional creatures were amphibians: tetrapodal creatures evolved from fish that are capable of living in water or on land. A

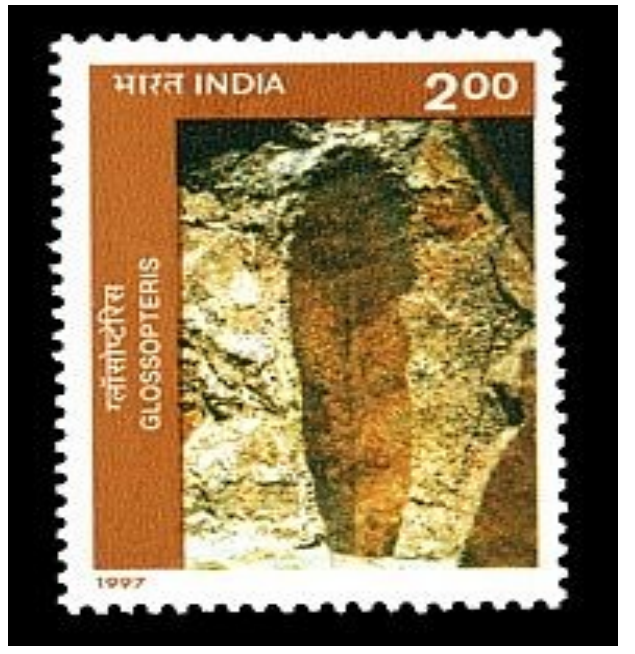

Illustration 4: Fossil Glossoptera. On the fiftieth anniversary of the Birbal Sahni Institute of Paleobotany, Lucknow, India issued a series of stamps picturing significant fossils. Glossopteris, the largest genus of seed ferns, is known only from its leaves which grew up to one meter (3.3 feet) in length. Since no fossils of woody parts have survived, its configuration as a plant, bush, or tree is unknown. Source: www.paleophilatelie.eu. 
huge data bank, Darrel Frost's Amphibian Species of the World (2006), lists hundreds; Ranjit Daniels's Amphibians of Peninsular India (2005) describes and pictures seventy-two, about one-third of the India total. Their proliferation and survival to the present is surprising since their navigation on land is often poor. With awkwardly placed limbs evolved from side-located fish fins, amphibians such as alligators and turtles experience a muscular challenge and are often poor travelers, walking on wide-spaced limbs and dragging a low, horizontal body along the ground.

In general, correction of this awkward limb placement had to await the emergence of reptiles. The legs of these cold-blooded, egg-laying tetrapods migrated under the body to provide vertical support. Having developed lungs, they no longer lived in water, though they often waded and hunted in it, immersing themselves only as short-term swimmers, never full-time residents. Three orders of reptiles have been identified in Indiain-Gondwana, including sixteen Families, with hundreds of species extant today: A Naturalist's Guide to the Reptiles of India (Das and Das 2018) provides a rich photographic survey of 280 species; R. Aengel's Checklist of Reptiles in India (2018) lists five hundred seventy-two.

The most dramatic reptiles were the dinosaurs that achieved faunal prominence in the mid-Triassic Era and dominated the planet for 165 million years (230 to 65 million years BP). P. C. Sereno et al. (1993) suggest that a small bipedal reptile about a meter in length called Eoraptor, "Dawn predator," that inhabited Western Gondwana (Argentina) 231-228 million years BP may be the ancestor that eventually bifurcated into 500 genera and $1000+$ species. Many, perhaps the majority, were small-the size of terrestrial birds or our familiar mammal species-with one well-known line experimenting with gigantism. The Tyrannosaur ("tyrant lizard") line, evolved a separate genealogy around 60 million years after Eoraptor, around 170 million BP. Tyrannosaurs were bipedal predators, but, as Stephen
Brusatte (2010, 2015) has shown, the 20 or so earliest varieties uncovered since 2000 from the Arctic, Russia, Mongolia, and North America were of modest size-some small, some not much bigger than domestic mammals. They tended to be overshadowed by the larger allosaurs and ceratosaurs, but ever since the largest Tyrannosaur, Tyrannosaurus rex ("tyrant king of lizards") was discovered in Montana in 1902, it has held center stage. However, the Tyrannosaur experiments with gigantism appear to have commenced with the extinction of allosaurs and ceratosaurs around 100 million years BP, with Tyrannosaurus rex achieving enormous size during the last 10 million years before the extinction of all the dinosaurs in 66 million BP.

Some 25 genera of dinosaur fossils are known from India-inGondwana. Their dates run from the earliest Mid-Triassic varieties to the modest-size predators of the Jurassic and Cretaceous Eras (230-66 million years BP). Like dinosaurs worldwide, these include bipedal and quadrupedal varieties that range in size from small to mid-size. Tyrannosaurus rex is absent from India and in fact from the southern continents; this enormous species evolved on the northern continents of Laurasia after it had separated from Gondwana. Thus dinosaur remains in India are confined to species that had evolved on the southern continents before the Laurasian separation from Gondwana. The iconic variety, with a symbolic Indian name, Rajasaurus ("king, sovereign, or royal lizard"), was roughly twenty feet in length (Wilson et al. 2003), half the length of Tyrannosaurus rex.

\section{Collision}

When Laurentia and Eurasia (= Laurasia) broke away from Pangea (200 to 180 million years BP), the Great Southern Continent of Gondwana remained intact; its southern continents dispersed at various later times. Prior to this breakup, during the Late Paleozoic Era (330 to 240 million years $\mathrm{BP})$, the Gondwana landmasses were subject to approximately 90 million years of glaciation-a result of supercontinent movement over a wandering
South Pole (Crowell and Frakes 1970, 1975; Crowell 1978). Geological effects of glaciation are evident in southeastern South America, Africa south of the Sahara, southern India, Madagascar, and Southern Australia. Around 100 million years ago India and Madagascar detached from Gondwana (Powell 1988), probably because of crustal rifting that separated them from the vast land mass of Antarctica. Today the Southwest Indian Ridge on the floor of the Indian Ocean marks the rift where, in all likelihood, an upwelling plume from deep in the Earth's mantle powered the separation, the opening of the southwest Indian Ocean, and the movement of the India plate north. Its estimated velocity was the fastest of any plate movement on the planet-twenty centimeters (7.9 inches) per year. Kumar et al. (2007) note that five seismographic stations on Archaean rock of the Indian Shield indicate a thickness of 80 to 100 kilometers ( 50 to 62 miles), about half the 180-kilometer thickness of the other Gondwana shields. It is thought that the base of the Indian Shield may have been eroded by passage over plumes or hotspots; in any case, its thinness may account for its unusually rapid migration. How much of the ocean bottom in advance of (to the north of) the India Plate was actually part of it is unknown for it exists now as deeplysubducted crustal fragments sinking into the mantle beneath Eurasia. Ocean bottom that trailed the India craton undoubtedly accumulated from upwelling along the Southwest Indian Ridge and consequent seafloor spreading.

When India began its migration north, the Indian subcontinent rafted a rock-and-fossil record that had accumulated over more than 3000 million years. An interwoven chronology of geotemporal, petrotemporal, and biotemporal events includes microfossils from Archean rocks, autotrophic bacteria, stromatolites, trilobites, vertebrates from fish to amphibians, and reptiles up to the great age of the dinosaurs. Some of these fossil remains indicate that parts of the India craton were periodically flooded during its migration, creating abovewater fossilization of undersea life. 


\section{(Illustration 5)}

As this cratonic raft moved away from Gondwana, existing species lived on. For perhaps 30 million years ( 96 to 66 million BP) late Cretaceous dinosaurs coexisted with diminutive mammalian species not much larger than a cat or dog that had long coexisted with dinosaurs since they had diverged from reptiles 225 to 200 million years ago. This India raft had moved far beyond its beginning point where it was attached to Antarctica and was halfway to Asia when a dramatic volcanism set in. The drifting subcontinent evidently ran over a deep mantle plume of enormous power that broke through the underlying crust and poured out massive quantities of lava which spread over a huge territory in western, central, and southern India. The resulting formation is known as the Deccan Traps, the latter a Scandinavian word that refers to a step or stair structure that was most likely formed from layers of lava overspreading earlier layers. The Deccan Traps today are up to 2000 meters (6600 feet) thick in the coastal region near Mumbai, tapering off to the east to less than 6o meters (under 200 feet). Upwelling lava was evidently superheated, resulting in an extended horizontal rather than vertical accumulation; virtually level lava flows have been traced for 100 kilometers (6o miles). The whole expanse is now spread over 500,000 $\mathrm{km}^{2}$ (200,000 miles $^{2}$ ), with a volume of $1,000,000$ $\mathrm{km}^{3}$ (200,000 miles ${ }^{3}$ ). However, nowseparated outliers indicate that extensive erosion has reduced both the thickness and area of the original Traps, which is estimated at three times its present size, making it one of the largest geological features on the planet. Fossils located between layers of lava indicate that eruptions were discontinuous, possibly recurring sporadically with pauses of tens of thousands of years, and coming to an end when the Indian subcontinent had moved clear of the underlying hotspot, which now lies under Réunion Island in the Indian Ocean.

A worldwide catastrophe occurred 66 million years BP when an asteroid struck Earth with an epicenter

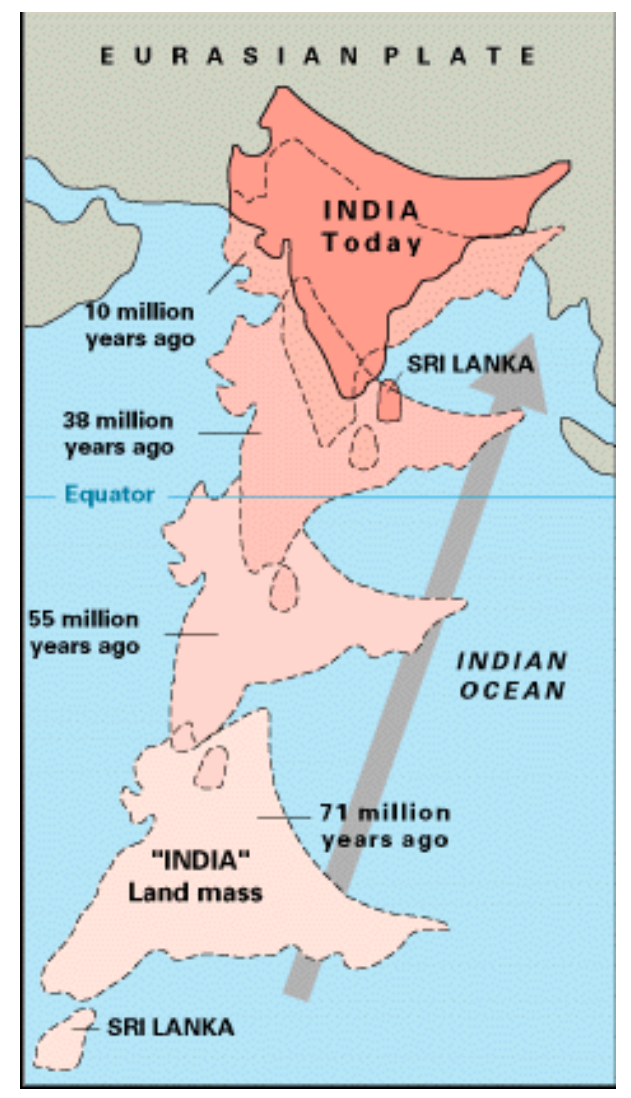

Illustration 5: Migration of India. Plate tectonics carried India north from Gondwana to its collision with South Asia. This illustration shows rapid movement (c. 20 $\mathrm{cm}$. per years) following departure from Gondwana gradually slowing to $5 \mathrm{~cm}$. per year as it approached South Asia. Source: en.wikipedia.com.

on the Yucatan Peninsula. The story of the Chicxulub impact can be traced through the geological work of the father-and-son, Luis and Walter Alvarez $(1980,1992,2017)$. Whether there is some connection between this impact and the eruption of the Deccan Traps has been put forward as tenuous theory but has not been demonstrated. The effect of the asteroid strike, however, was a worldwide mass extinction that eliminated $90 \%$ of terrestrial life, with dinosaurs in India and elsewhere driven to extinction. The Indian subcontinent thus became a graveyard for the last Cretaceous Era dinosaurs, including Rajasaurus. The inventory of dinosaur remains in India, however, does not include the enormous Tyrannosaurus rex or its smaller ancestors, for the Tyrannosaur line seems to have developed on Laurasia after separation from Gondwana; it is thus found in northern regions-China and North America (Brusatte et al. 2010; 2015). Among the mid-sized dinosaur remains in India, the extensive collection of bones near Balasinor in the western province of Gujarat ranks as one of the most prominent fossil sites in the world. Here dinosaur bones are spread over $70+$ acres, littering the surface of the ground; fossilized dinosaur eggs have been located; and scores of skeletal remains of numerous species have been preserved. The Suketi Fossil Park on the bank of the River Markanda, in Nahan, preserves a different era of prehistoric lifeprimarily vertebrate fossils and skeletons.

The striking uniqueness of India is its collision with South Asia and the profound geographical effect this impact had. Recent studies (von Hinsbergen et al. 2012; Jagoutz et al. 2015) have placed the collision of the Indian craton with offshore islands of Eurasia at 50 million years BP and collision with the Eurasian landmass 10 million years later. If this chronology is accurate, the extinction of late Cretaceous dinosaurs happened approximately 26 million years before India became part of Asia. Species that survived the mass extinction included smaller amphibians, reptiles, avian dinosaurs (birds), and mammals that now emerged as the dominant species. While some evolutionary development of surviving species undoubtedly occurred in India between its separation from Gondwana and suturing to South Asia, the subsequent 40-million-year movement of species between Asia and the Indian subcontinent has rendered these less significant today. Within a few million years, India's animal population included species originating in the immense landmass of Eurasia.

The migration of India north from Gondwana to the south coast of Eurasia was largely marked by the preservation of lifeforms along with an immensely long fossil record of their history. Meanwhile, the collision of the Indian craton with Southern Asia began one of the most dramatic events of planetary history. With the collision of the subcontinent with offshore 
islands (c. 50 million BP), the collection of island terranes began, though they were subsequently crushed or subducted. With the full-bodied meeting of India with the Asian mainland, a slow-motion 40-million-year collision was set in motion which is still going on. Prior to the collision, the India plate set a tectonic speed record, moving at 20 centimeters (7.9 inches) per year (Kumar 2007). Since the collision, movement has gradually slowed to the present 5 centimeters ( 2 inches) per year. One way of observing the effect of India's continuing collision suggested by Krishnan $(1982,73)$ is the distortion of the Tethyan Basin (the last remnant of the Tethys Sea, which separated Laurasia from Gondwana in the pre-Cretaceous Period). This basin can be traced from Turkey through Iraq and Iran and it may have run as a straight line into the Indonesian Archipelago. This suggestive calculation indicates that the collisional mass of India has pushed the basin north by approximately 1300 kilometers (780 miles). The result was a progressive crushing of landmasses that reduced the area of land along the line of collision. Krishnan, who has written extensively on Indian tectonics (1953; 1967), concludes that "the estimate of the crustal shortening of about $1300 \mathrm{~km}$. . . would therefore seem to be quite a modest estimate for the numerous folds, overthrusts and nappes present in the Himalayan-Karakorum belt" which indicates that "a region of great width was involved in the Tertiary mountain building movements" (1982, 74 ). While the precise reduction in area may remain beyond precise determination, the impact region is highly visible (Illustration 6), and the volume of rock and sediment affected is incalculable, though the result is obvious. The entire region north of India, including both the Himalayas and the Tibet Plateau, has been forced upward by this landmass collision. What is visible, however, is a partial picture. When continental crust attains elevation through orogeny (mountain building), it also gains depth or thickness that displaces some of the underlying mantle, thus maintaining its buoyancy, like a loaded ship settling

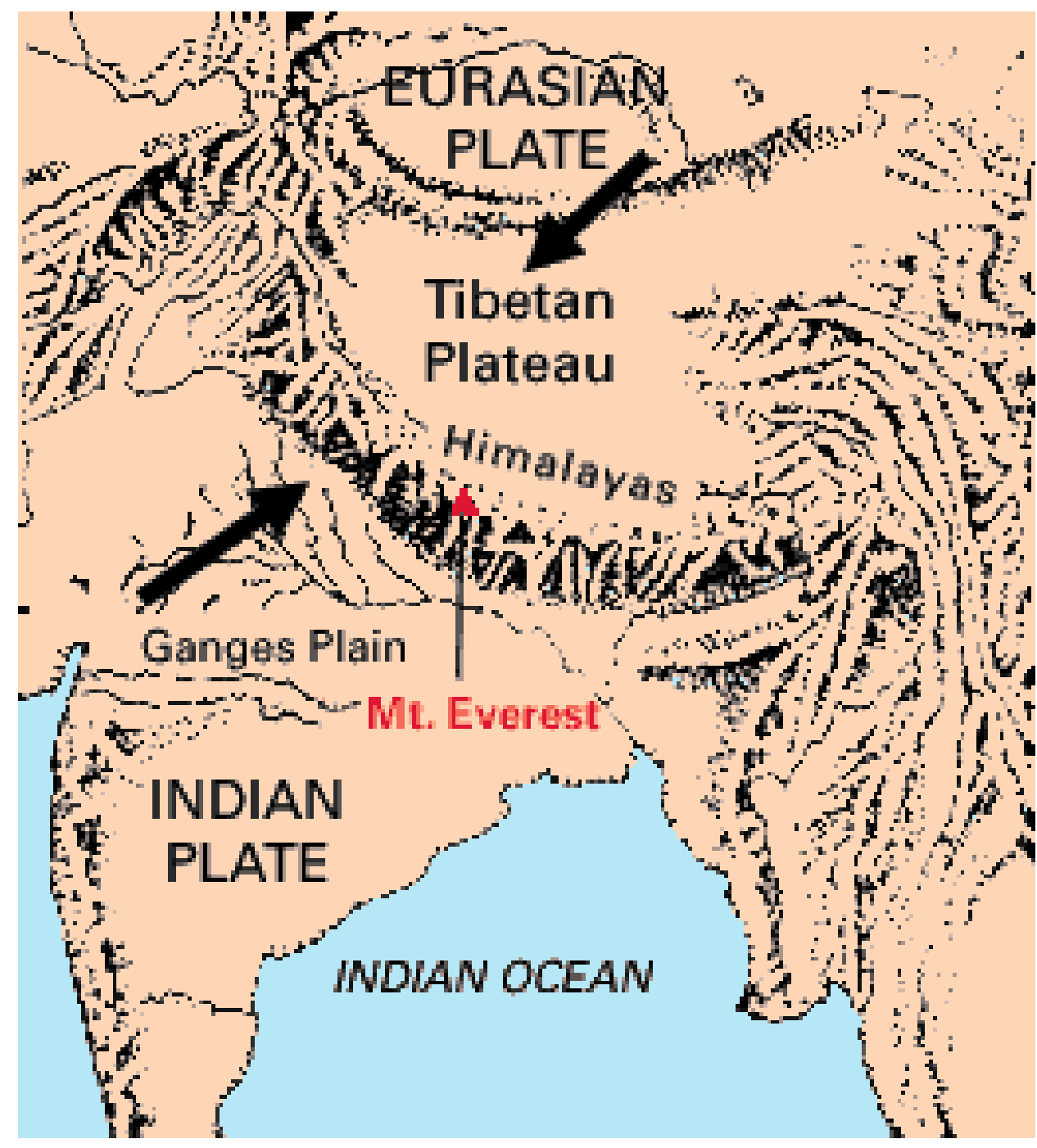

Illustration 6: Collision with South Asia. The crushing and collision of landmasses is visible in the distorted lines of the Himalayas and the complex mountainous ripples at both ends of the range. The raising of the mountains outpaces erosion caused by wind, rain, snow, avalanches, and rock slides. The area of Asia affected is several hundred miles in width and more than 1500 miles from east to west. Source: www.usgs.com.

\section{deeper into the water.}

The present location of India today presents some striking facts of chronology. During its extensive prehistory, India was elsewhere. Its history of stromatolites and trilobites, fish and amphibians, reptiles and dinosaurs and early mammals occurred while it was part of a sequence of supercontinents extending far back in time: Pangea, Gondwana, Atlantica, Rodinia, and Ur. The whole time span since verifiable life began is 3500 million years while the time India has been a part of Asia is 50 million years. In a scale we can understand, $97.7 \%$ of India's geological and biological past occurred elsewhere with the time India was part of Asia calculating to 1.3\% of her history. In the final phase of its history, India provides a unique example of continental migration with a collision more momentous than others around the planet. In addition, India reminds us that every craton, terrane, region, and nation has an equally vast prehistory that unfolded elsewhere from where it is now. It has been estimated that most of the continental landmasses of the world have moved at least 10,00o miles. Alfred Wegener would be amazed.

At less than 50 million years of age, the Himalayas make up the newest mountain range on Earth. Their peaks are craggy and jagged and constructed of huge slabs of obducted crust and sedimentary rock. Observation 
confirms that the direct impact of convergent plates slowly folded, rippled, crumpled, crushed, and buckled huge slabs of surface crust which have been steadily thrust upward, adding to the overall height of the entire range (Illustration No. 7). Embedded in sedimentary rock, shells, trilobites, and other fossils mark the rippling and folding of seabed forced over the Asian continent. Among these the oldest whale fossil on the planet was discovered (Bajpai 1998): Himalayacetus subathuensis, a mammal that returned to the ocean-perhaps to the Tethys Sea. Dating to the Eocene Era 53.5 million years ago, it is one of several Eocene mammal fossils found in the Himalayas (Thewissen 2001).

The highest peak in the world, Mount Everest, stands at 29,017 feet (29,029 to the top of the snow), but the Himalayan range features fifty mountains over 7,200 meters $(23,600$ feet). The range varies from 150 kilometers (90 miles) to 350 kilometers
(220 miles) in width and stretches 2400 kilometers $(1,500$ miles $)$ across northern India. Immediately north, a tectonic valley roughly 30 to 35 miles across - the remnants of the Tethyan Ocean basin-separates the Himalayas from the Tibetan Plateau, a 2.5- million-square-kilometer (970,00o-square mile) plateau averaging 4,500 meters $(14,8$ oo feet) above sea level. The volume of all this land displaced and thrust upwards is unimaginable, though the collisional history of the planet suggests immense changes on this scale have happened many times in many locations. Meanwhile the increase in elevation outpaces erosion which began as soon as the first hills were pushed up 40 million years ago. The result is the deep, rich, erosionfed lands immediately south of the range that form a fertile belt across the north of India. The four greatest rivers of South Asia-the Indus, Ganges, Brahmaputra, and Mekong-are fed by Himalayan ice and snow with mas- sive flows from mountain elevations.

\section{Culture}

When we consider our bipedal ancestors around five million years ago, we are confined to the miniscule fraction of time when India was part of Asia. If we focus our perspective to the whole time of Homo sapiens, we are more confined to 300 thousand years, a vanishing fraction of the whole. Yet our day-to-day perspective, in India and everywhere else is so consumed by the human concerns of families, friends, school, work and recreation that these easily swell to become our major or even our only perspective. From this viewpoint, earth and biological history can easily disappear like the splash of stars in the Milky Way now mostly out of sight beyond our dust-laden skies. We need a double perspective. No matter how consuming our lives may be, there is a larger story where the groundwork and possibility for our existence was laid down over

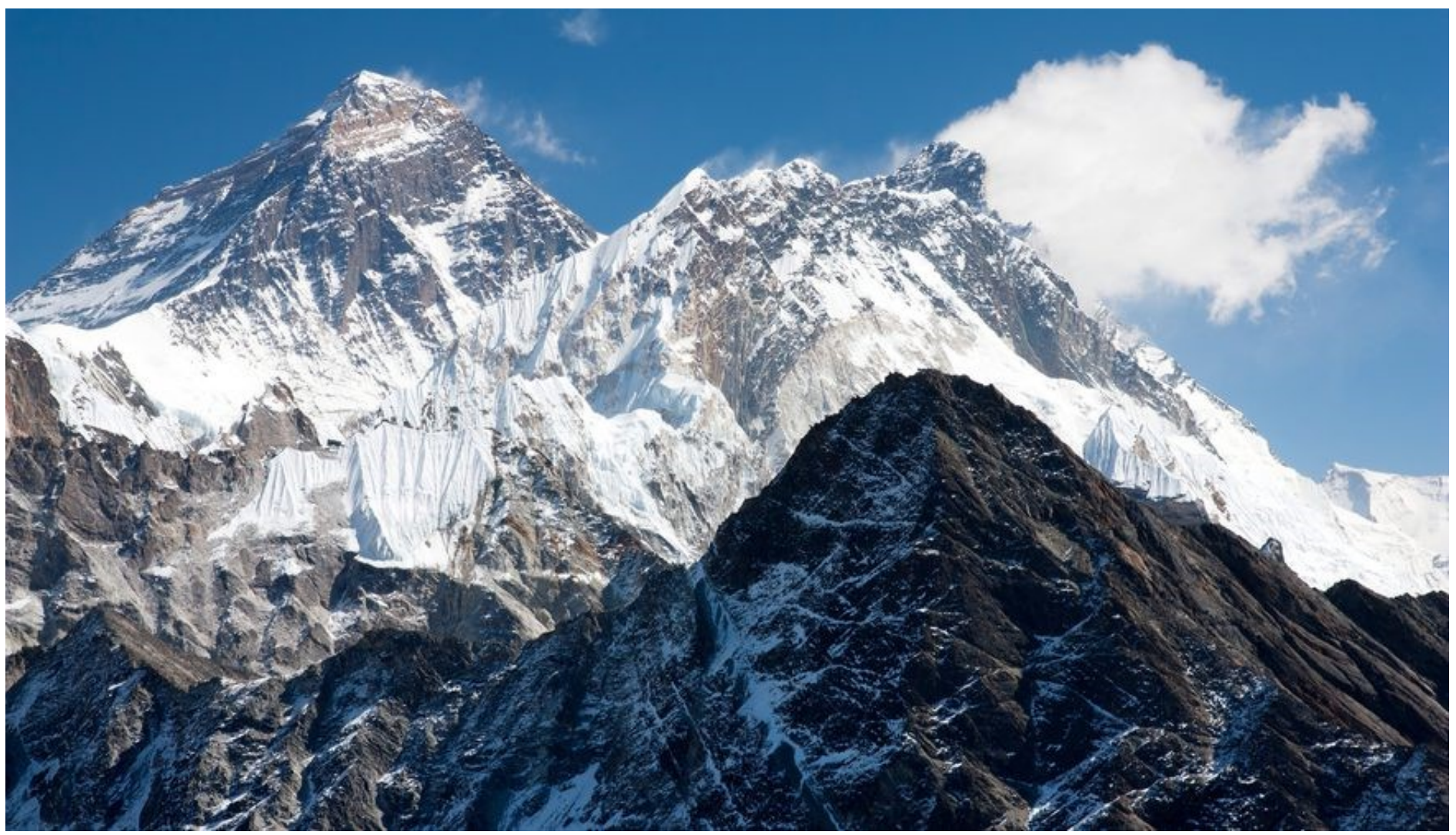

Illustration 7: The Himalayas. The collision of India with Southern Asia led to a crushing and compression of thousands of square miles of landmass that subducted, obducted, and rippled, leading to a deep thickening of continental crust while raising the greatest mountain range on the planet, and creating the Tibetan Plateau. Beginning 50 million years ago, the collision continues today, raising the mountains an average five millimeters a year. Continuing mountain erosion has result in the rich fertile lands of northern India and the Indus, Ganges, and Brahmaputra River Valleys. Source: www.sciencing.com. 
billions of years on long forgotten earthscapes. Our significance lies in our ability to imagine the whole story: to realize the place of humanity in the light of this immense prehistory. India provides one of many landscapes for exploring our imaginings.

In the past thirty years we have recognized that Homo sapiens migrated out of Africa some time earlier than 65,000 years BP. A growing list of sites and artifacts has shown us that the primary migration route out of Africa was across the Gate of Grief at the south end of the Red Sea to the southern coast of Arabia (Armitage 2011) now called the Southern Route. In fact, an extensive sequence of artifacts, human remains, and relict settlements along oceanic margins indicates that the primary route that peopled the world was coastal-following the shorelines of South Asia, then beachcombing around the entire Pacific Ocean from Philippines to Patagonia (Wood 2019b). Genetic markers coastal migrants into India, or what Reich et al. (2009) call Ancestral South Indians, provided one of the two major gene pools of India today. Metspalu et al. (2004) suggest that the fertile ecology of India may have made it a primary stopping point for some coastal migrants. Undoubtedly, numerous South Asia rivers-the Indus, Narmada, Sabarmati, Krishna, Godavari, Brahmani, Ganges, and Brahmaputra-would have invited inland riverine migration. But geological events constrained the chronology of human occupation of India. The Mount Toba explosion in Sumatra that dates to 74,00o BP provides an important milestone. As Stephen Oppenheimer (2004) notes, the Mount Toba explosion is thought to have caused such extensive deforestation, ash fall, and ecological damage in India that humans already there might not have survived. Tools atop volcanic ash at Jwalapuram on the Krishna River indicate settlement occurred soon after the Mount Toba event. In general, Homo sapiens in India over the next 65,000 years were nomadic huntergatherers (Misra 2001), most likely clustered into tribal units of approximately thirty individuals, which Lee and DeVore (1968) have suggested was the "magic number" for prehistoric band size.

The second gene pool dominant in India, identified by Reich et al. (2009) as Ancestral North Indians, were later migrants from the Iran and the Middle East, and points farther north. More than two hundred years ago, this migration became an inevitable assumption when Sir William Jones made his presentation in the Third Discourse to the Asiatic Society (1786) in Calcutta, identifying Sanskrit and derivative languages as belonging to what is now known as the IndoEuropean language family (Cannon 1990). Subsequent research has shown that this family originated in the region of the Black Sea, near or east of Ukraine or possibly Anatolia (Ruhlen 1994). Indo-European peoples had thus migrated, following the east coast of the Persian Gulf into the Indus River Valley, and mingled with the indigenous nomadic people in the region. Historically, they called themselves "Aryans," a term recording the most recent leg of their migration routeout of Iran. Genetic evidence of lactose tolerance among these migrants suggests they arrived after the Agricultural Revolution in the Middle East which dates from 12,000 to $10,000 \mathrm{BP}$ (Maisels 1990, 65-77). Their arrival with agricultural skills in what is now Pakistan is typically placed around 5000 BCE. By 3000 the Indus River Valley was cultivated extensively enough to support numerous permanent settlements; by $2700 \mathrm{BCE}$ the dominant cities of Harappa and Mohenjo-daro represented the high point of Indus Valley culture (Kenoyer 1998). Asko Parpola (2015) confirms the longstanding theory that these migrants established the roots of Hinduism. Sir William Jones had concluded as much in the 1780s: the Hindu Vedas and Upanishads were written in Sanskrit, the earliest extant Indo-European language-a clear indication that these northern migrants provided not only the language but also the fundamental concepts and beliefs that evolved into Hinduism (Basham 1954; 1991).

The history of India over the past 3000 to 4000 years is encyclopedic in complexity and detail; it began with the decline of the Indus Valley Civilization between 2500 and 1900 BCE (Possehi 1997) and a demographic shift to the upper Ganges-Yamuna River Valleys. Here the Hindu religion matured, though its roots had been established millennia earlier. The nexus of the Hindu-Buddhist civilization, which was primarily mythic, laid out broad parameters that underlie the subsequent cultural history of India. The earliest spiritual texts were the Vedas; of four collections, the Rig Veda is the oldest, having been transmitted orally and musically for almost 3,000 years until it was given written form in ancient Sanskrit between 1500 and 900 BCE (Basham 1991). The Rig Veda consists of 1,028 hymns that are addressed to early deities (250 celebrated Brahma, the god of creation) and appear to be musical accompaniments to ritual originating in the Indus Valley Civilization.

It is rare that a single text can capture the essence of an entire culture, but Rig Veda x.9o manages just that. According to this hymn, creation began by the sacrifice of Purusha Suk$t a$, the Cosmic Man, who had a thousand heads and equally prolific number of arms and legs. His sacrifice, which resembles an "Indo-European corpus of myths of dismemberment" (O'Flaherty 1981, 19), transforms him into the world, sky, Sun, and Moon; all the wild and domesticated animals of the Earth; the four seasons; the entire hierarchy of human society from Brahmins to warriors to farmers, and servants. From his sacrifice even the Vedas were created, including the Rig Veda where this hymn appears. From the various parts of his body, too, the gods are born-the supreme deities, Indra and Agni, from his mouth - a remarkable detail that suggests that the gods themselves come from the mind and words of man himself. The symbolism of this hymn and its connection to other Hindu writings deserves the attention of anyone seeking to understand the roots of Indian culture (Wood 2017). The overall structure of this narrative says that the multiple heads and limbs of the Cosmic Man are in fact the heads and 
limbs of all humankind, $7+$ billion heads and double that number of arms and legs, though they cohere as a spiritual unity originating in the creative event itself and evident in the history of Indian society for the past thirty centuries.

The unity of humankind in India earned further confirmation in the Upanishads. The word means "forest discourses." These were one hundred nine philosophical writings composed by spiritual philosophers-ascetics who escaped to isolated forest settings, thus setting themselves apart from society to pursue the enlightenment known as moksha: the realization that one's atman (the individual self) is one with Brahman (the cosmic self). This ultimate discovery is summarized in the Chandogya Upanishad as Tat tvam Asi (VII, viii, 7), "That art Thou," colloquially, "You are It." No matter how many divisions occur, no matter how many conflicting interests appear, no matter what other religions, beliefs, philosophies, ideologies may arise in India, the central truths of the Rig Veda and the Upanishads assert the underlying unity of the cosmos, world, society, and humankind. This realization is the culmination of the Indian epic, the grand narrative of the making of India.

There are, however, two other discoveries in Indian culture. They do not contradict what these earlier texts assert; rather they deepen and broaden their truths, and remarkably, they seem intuitively to recognize the ancient roots of India that extend deep into the past before civilization and culture existed. One of these recognitions is that the everyday time, clock time, the constricted time of mere decades, centuries, or millennia fails to do justice to India and its understanding of the Infinite. The bestknown text of India is the Ramaya$n a$-most of it available in the Clay Sanskrit Library (Goldman et al. 20052006) - a magnificent epic of betrayal, exile, love, rescue, and kingship. As V. Raghavan (1980) assembled in a landmark conference and forty-four regional essays, the Ramayana influence has touched nearly every culture in Asia. It is so powerful, so magnificent, so cosmic in scope, that it has inspired cultures across what Ptolemy labeled on his map INDIA EXTRA GANGEM, "India beyond the Ganges" (Ptolemy 1991) where it has been translated multiple times in Myanmar, Thailand, and Indonesia and its episodes have been sculpted on temples from Bangkok's Grand Palace in Bangkok, Angkor Wat in Kamboja, the Prambanan Temple in Central Java, Majapahit temples in East Java, and carvings in dramatic relief on the island of Bali (Illustration No. 8).

The central narrative is the captivity of the princess Sita and her dramatic rescue by prince Rama. The story is too complex to summarize, but the narrative unfolds against a time frame unknown in Western literature. Before Rama was born, his father Dasaratha ruled the kingdom of Ayodhya for 6o,ooo years; after Rama rescues Sita and takes up the kingship, he rules the kingdom for more than 10,000 years. This, of course, is literary myth, but intuitively it tells us that the world and the universe as conceived in India are much greater, with a much longer history, than the mere centuries of present civilization.

A similar mythic temporality is found in the Buddhist tradition. The story of Siddhartha, the prince of a kingdom at Lumbini, now in Nepal, is well known: having witnessed suffering, he left the kingdom behind, sought enlightenment among the forest sages, then ultimately attained enlightenment on his own, from which point he was known as the Buddha. His wisdom is summarized in the Four Noble Truths and the Noble Eightfold Path (Walshe 1995). Following his death a body of legends known as the Jataka Tales took shape as one of the earliest literary collections from India. The tales, which have origins in the fourth century $\mathrm{BCE}$, appear to be a folkloric collection, many of them animal tales somewhat like Aesop's fables that have migrated into the Buddhist canon. Here they take the form of lives of former Buddhas (Cowell 1895), each one "containing the life of Buddha during some incarnation in one of his previous existences as a Bodhi- satta" (Francis and Thomas 1987, 5). According to the mythology that developed around the Buddha (560-48o $\mathrm{BCE}$ ), he was the most recent of twenty-five Buddhas born at intervals of 5,00o years. People routinely forget the message of the Buddha; hence it is necessary that he regularly return to renew the Four Noble Truths and the Eightfold Path. Simple mathematics shows that this sequence of earlier Buddhas extends over 125,000 years. The mythology behind the Jataka Tales "has little to do with the fundamental teachings of Buddhism" (Conze 1951, 97), and has no part in the profoundly complex philosophy of Buddhism (Guenther 1972). But the mythology itself constitutes further evidence that history and prehistory in India is conceptually far more expansive than other temporal

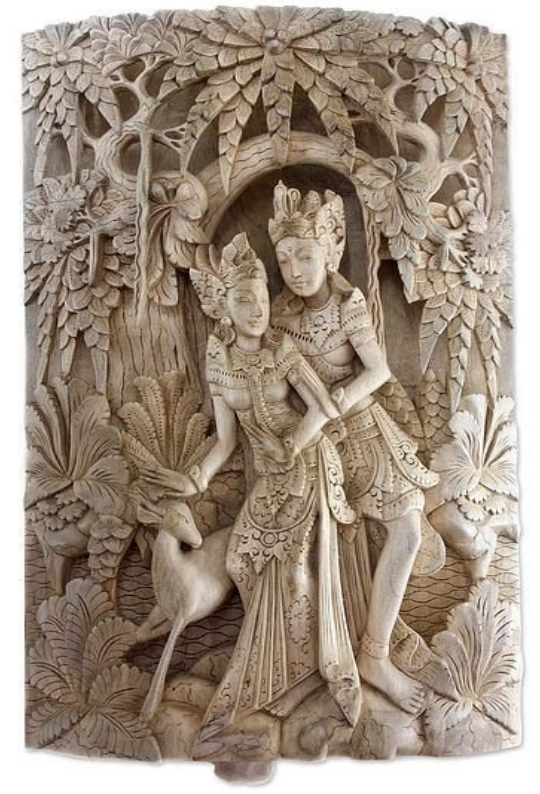

Illustration 8: Rama and Sita. Although the Ramayana epic is dominated by jealousy, betrayal, kidnapping, abuse, and war, its underlying story is the captivating love between king Rama and Queen Sita who suffer through exile and Sita's captivity to attain their rightful destiny as king and queen of the kingdom of Ayodha. Episodes from the story appear in sculptured temple panels from India to Indonesia. Pictured here is a woodcarving from the Island of Bali, recognized worldwide for its painting, carving, sculpture, music, and drama. Source: www.Pinterest.com. 
traditions. Moreover, it constitutes a fictional history that adds to the authority and power of Buddha and Buddhism.

While Hinduism has provided a power culture for India that continues today, the practice and theory of Buddhism gained its greatest strength elsewhere: in Sri Lanka, Myanmar, Thailand, with influence in Malaysia, Indonesia, China, and Japan. Its greatest monument is Borobudur in Central Java, now a UNESCO World Heritage Site (Illustration No. 9).

This Buddhist view of time underlying the Jataka Tales, greatly expanded, informs the Indian Mahabharata, though on a much grander scale. This ancient epic is the longest literary work ever composed. The title means "great" (maha) "cherished one," (bharat) and refers to the father of two brothers, Bharat, and thus the ancestor of the two tribes descended from these brothers, the Pandavas and the Kauravas. A disequilibrium in human society occurs when the two brothers fall into conflict. Subsequently, their contentious relationship is passed on to future generations to become a blood feud between rival clans. A vast time scheme, which is also described in the Vishnu Purana, lies behind the Mahabharata. Its units are yugas and kalpas. As Troy Wilson Organ (1974) clarifies, history unfolds through four yugas, or "great years": the Satya, Dvapara, Treta, and Kali Yugas stretched through 1,728,ooo, 1,296,ooo, 864,000 , and 432 ,ooo years for a total of 4,320,000 years, known as a kalpa. Rama, we learn, lived in the second age of the world, presumably the Dvapara Yuga, which situates the story of the Ramayana well over a million years in the past. The Mahabharata feud occurred many thousands of years in the past toward the end of the Treta Yuga. Indians intuitively understood that present human life occurs in a minor sliver of time within an infinitely long history and prehistory. In his presentation of "India and the Infinite" (1979) religion historian Huston Smith pointed out that while the West was still thinking the world might be no more than 6 ,ooo years old, India was already envisioning

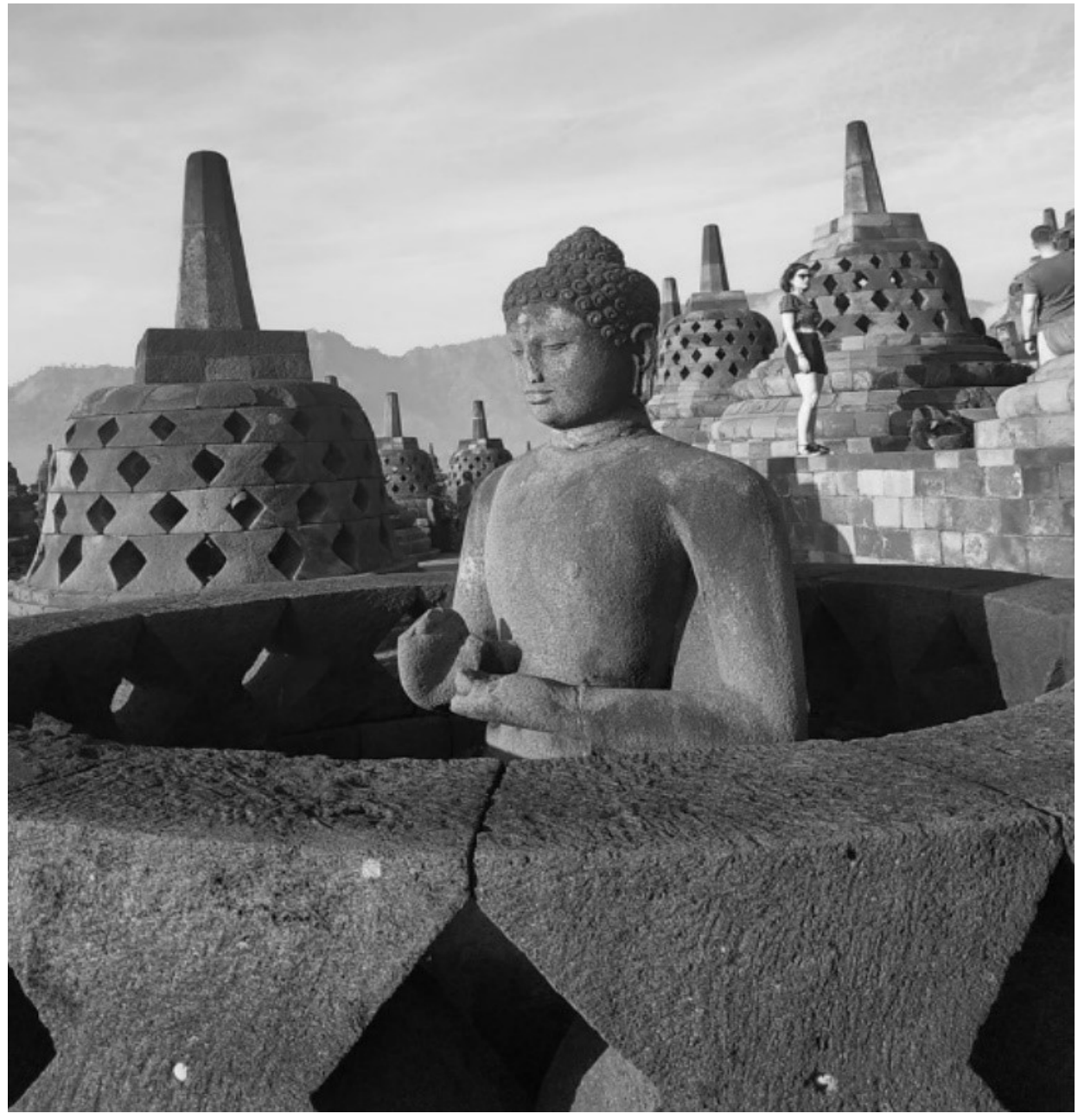

Illustration 9: Borobudur. The largest Buddhist stupa in the world, Borobudur, a square pyramidal structure 118 meters (387 feet) per side, is located in Central Java, Indonesia. It has six square lower levels and three circular upper levels topped by a large central stupa surrounded by an array of smaller bell-shaped stupas. Built over an estimated 75 years, its completion is estimated at $825 \mathrm{CE}$. The lower levels display 2,672 relief carvings that stretch for hundreds of yards. Of the 504 statues of Buddha, seventy-one are seated in bell-shaped stupas on the top levels (shown in the background) and can be viewed through diamond-shaped openings. In the foreground, one stupa was deliberately left incomplete. Following a $9^{\text {th }}$ or $10^{\text {th }}$ century eruption of nearby Mount Merapi the monument was covered with volcanic ash and jungle growth; thus the monument disappeared for several hundred years, known only as hidden ruins by indigenous locals. Rediscovered early in the $19^{\text {th }}$ century, the monument was cleared of trees and ash by Sir Stanford Raffles. Source: www.unsplash.com.

time stretching into an infinite past and a universe of endless galaxies so vast that modern astronomy slips into its fold without a ripple. The correlation of this mythic temporality with the geotemporality, petrotemporality, and biotemporality of India's pastmost of it in India-in-Gondwanaunifies science, philosophy, and spirituality in a manner unique to human civilization.

But lest we seem to overpraise India's intuitive grasp of this larger reality, we need to emphasize the massive tragedy also realized and articulated in Indian philosophy. Siddhartha, who became the Buddha, was motivated by witnessing hunger, sickness, suffering, and death. His Four Noble Truths include the facts that "existence is suffering" and "suffering is caused by selfish craving." This is the ongoing fate of every human, but another great truth is that selfish can be overcome by following the Noble Eightfold Path allegedly uttered by 
Buddha himself at Benares following his enlightenment

A variant presentation of human suffering and selfish craving on a massive scale appears in the Mahabharata epic. As this enormous story unfolds, generation after generation, the feuding clans grow in numbers. Eventually, after millennia of feuding, they number in the hundreds of thousands, but no one remembers what the original feud between the brothers was all about. Moreover, the warring clans have forgotten the primary truth that all humans are ultimately brothersand sisters, cousins, aunts and uncles, nephews and nieces. Everyone on Earth is related, as in fact genetically we are. The realization of this tragedy comes in a collection of eighteen chapters in The Mahabharata when the armies of the Pandavas and Kauravas, descendants of the original feuding brothers, are drawn up on the battlefield before dawn, ready to begin the final, decisive war, scenes from which have been carved in temples across Southeast Asia (Illustration 10). These chapters have taken on a life of their own; they make up the Bhagavad Gita, the central spiritual text of Hinduism. The action focuses on a warrior in a war chariot, Arjuna, and his dialogue with his charioteer, who happens to be the god Krishna in disguise. In despair, Arjuna looks out through the mist of morning at the vast armies waiting for the full light of dawn and asks his charioteer what it all could mean.

The answers Krishna provides to Arjuna's questions provide a systematic presentation of Hindu thought and practice, specifically the many ways that humans may overcome egotism and selfish craving and pursue spirituality: the many paths to enlightenment available to people from different levels of society. There are meditational paths, paths through learning and wisdom and work, family life, devotion and love. All of these are different forms of yoga-"disciplines" that are equally important in the human quest for knowledge, wisdom, truth, and unity. With this wisdom understood, the tragedy of war now fits into the larger scheme of things, and the war begins.

As we look at Indian culture, we are likely to think of Hinduism as a "religion," but it is so much more. It is a culture that penetrates ever dimension of Indian life. It is not likely that it can solve the problem of armies prepared to fight against their own kin; that is the virtually unsolvable tragedy of human history, of wars that have besieged the underlying unity of human life since civilization began, and they continue today. Amid this tragedy, however, the underlying unity of life remains, and there are many paths to that realization. Our understanding of Hindu culture is too small; seen in its entirely, it is a final episode in an epic journey "from atoms to atman," a grand narrative tracing out the emergence of infinite spirit (Wood 2017). The multiple paths confirm that all of human life-every path, every practice, every task, every human endeavor-is central to the task of finding one's way

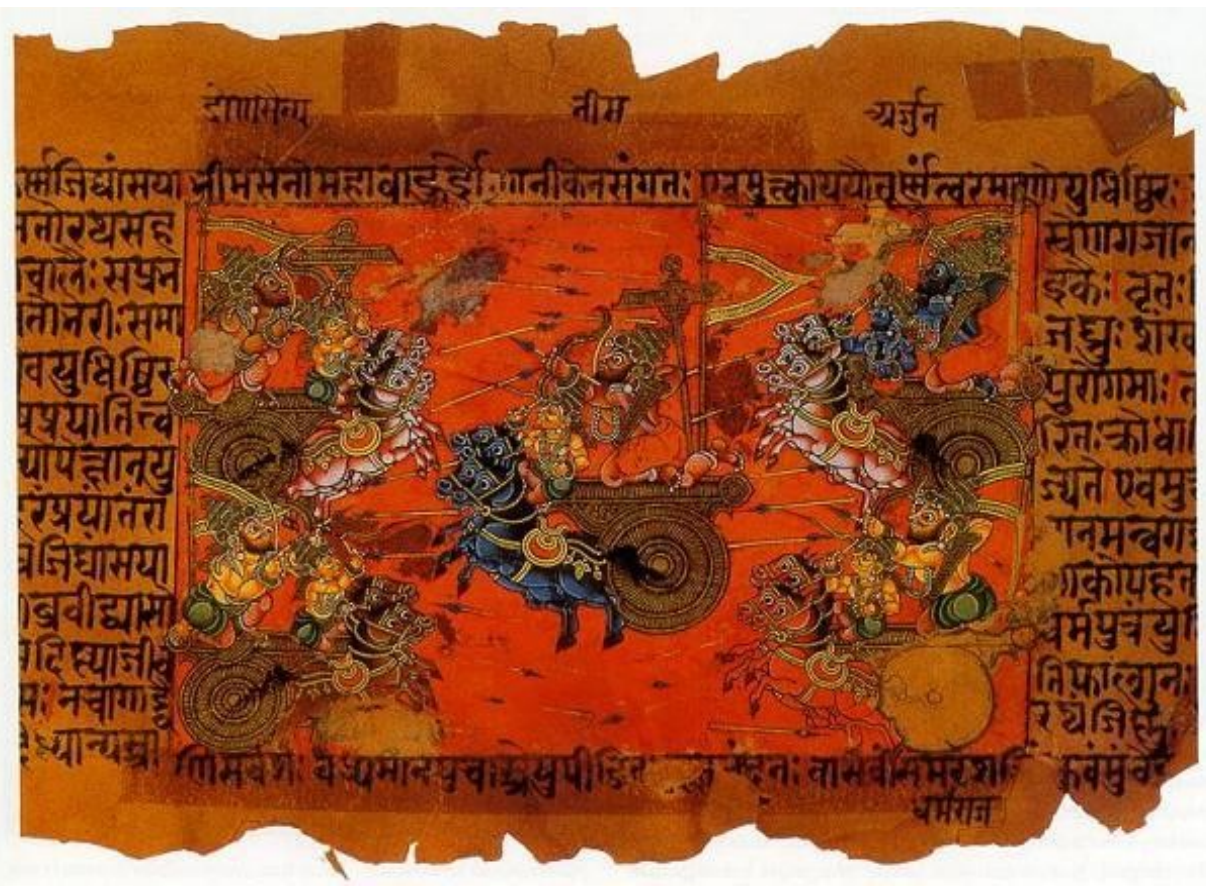

Illustration 10: The Mahabharata War. A manuscript scene of Arjuna and his charioteer in the thick of the final battle between the Pandavas and Kuravas. Eighteen chapters of the enormous Mahabharata epic that precede this battle make up The Bhagavad Gita, the most sacred of Hindu texts, where Krishna, disguised as Arjuna's charioteer, explains the multiple ways to moksha (enlightenment) - the many yogas of work, study, family life, service, meditation. These spiritual truths mitigate the tragedy of war between two clans descended from feuding bothers, sons of the ancient king, Bharat. The war led to 1,660,020,000 deaths, approximately 300 million more than the present (2019) population of India. Source: https://isha.sadhguru.org. 


\section{References}

Aengals, V. M. et al. 2018. A Checklist of Reptiles of India. New Alipore, Kolkata:

Zoological Survey of India. Online publication: www.zsi.gov.in.

Aitchison, Jonathan C. et al. 2007. "When and Where Did India and Asia Collide?" Journal of Geophysical Research. https:// doi.org/10.1029/2006JBoo4706. Accessed 10 July 2019.

Alvarez, Luis W. et al. 1980. "Extraterrestrial Cause for the Cretaceous-Tertiary Extinction." Science, Vol. 208: 1095-1108.

Alvarez, Walter. 1997. T-Rex and the Crater of Doom. Princeton: Princeton University Press.

Alvarez, Walter. 2017. A Most Improbable Journey: A Big History of Our Planet and Ourselves. New York: W. W. Norton.

Armbrust, E. Virginia, and Stephen Palumbi. 2015. "Uncovering Hidden Worlds of Ocean Biodiversity," Science 348, no. 6237: 865867.

Armitage, Simon J., et al. 2011. "The Southern Route 'out of Africa': Evidence for an Early Expansion of Modern Humans into Arabia." Science 331, no. 6016: 453-56.

Bajpai, Sunil and Philip D. Gingerich. 1998. "A New Eocene Archaeocete (Mammalia, Cetacea) from India and the time of Origin of Whales." Publications of the National Academy of Sciences (PNAS) 95 (26): 15464-15468.

Ballard, Robert D. 20oo. Eternal Darkness: A Personal History of Deep Sea Exploration. Princeton: Princeton University Press.

Basham, A. L. 1954. The Wonder That Was India. Expanded edition. Calcutta: Rupa \& Company.

- - . 1991. The Origins and Development of Classical Hinduism. Boston: Beacon Press.

Basu, A. R. et al. 198o. "Eastern Indian 380o-Million-Year-Old Crust and Early Mantle Differentiation." Science 212, no. 4502:1501-1506.

Briggs Derek E. G. et al. 1994. The Fossils of the Burgess Shale. Washington, DC: Smithsonian Insti- tute.

Brusatte, Stephen, et al. 2010.

“Tyrannosaur Paleobiology: New

Research on Ancient Exemplar

Organisms." Science 329: 1481-

1485.

Brusatte, Stephen. 2015. "Rise of the Tyrannosaurs." Scientific American 312, no. 5 (May): 34-41.

Cannon, Garland. 1990. The Life and Mind of Oriental Jones. Cambridge: University of Cambridge Press.

Chandra, S. and K. R. Surange. 1979. "Revision of the Indian Species of Glossopteris." Monograph 2. Birbal Sahni Institute of Palaeobotany, Lucknow. 301 pp.

Clarkson, E. N. K. 2006. "The Eyes of Trilobites: The Oldest Preserved Visual System." Arthropod Structure E Development 35: 247-259.

Conway, Morris S. 1979. "Middle Cambrian Polychaetes from the Burgess Shale of British Columbia." Philosophical Transactions of the Royal Society, London B. 285: 227 -274 .

Conway Morris S, and J. B. Caron. 2012. "Pikaia gracilens Walcott, a Stem-group Chordate from the Middle Cambrian of British Columbia." Biological Reviews 87: 480-512.

Conze, Edward, 1959. Buddhism: Its Essence and Development. New York: Harper Torchbooks.

Cowell, E. B.; ed. 1895. "The Jataka or Stories of the Buddha's Former Births," Vol.1-6, Cambridge.

Crowell, J. C. 1978. "Gondwanan Glaciation, Cyclotherms, Continental Positioning, and Climate Change." American Journal of Science 278: 1345-1372.

Crowell, J. C., and L. A. Frakes. 1970. Phanerozoic Ice Ages and the Causes of Ice Ages, American Journal of Science 268: 193-224.

___ 1975. "The Late Paleozoic Glaciation.” In Gondwana Geology. Ed. K. S. W. Campbell. Canberra: Australian National University Press. 313-331.

Daniels, Ranjit. 2005. Amphibians of Peninsular India. Himayatnagar, Hyderabad: Universities Press.

Das, Indraneil, and Abhijit Das. 2018.
A Naturalist's Guide to the Reptiles of India. Oxford: John Beaufoy Publishing.

Dietz, Robert S. 1961. "Continent and Ocean Basin Evolution by Spreading of the Sea Floor." Nature 190, no. 4779: 854-857.

Dodd, Matthew S. et al. 2017. "Evidence for Early Life in Earth's Oldest Hydrothermal Vent Precipitates." Nature 543, no. 7643: 6o-64.

Feistmantel, O. 1876. "Contributions Towards the Knowledge of the Fossil Flora in India: On Some Fossil Plants from the Damuda Series in the Raniganj Coalfield," Collected by Mr. J. Wood-Mason" Journal of the Asiatic Society of Bengal, Part 2, Natural Science 45 pt.2 (Contr. 19):329-382 (4): 329382.

Francis and Thomas, eds. 1987. Jataka Tales. Bombay: Jaico Publishing House.

Froese, R. and D. Pauly, eds. 2006. FishBase. World Wide Web electronic publication.

Frost, Darrel R. 2006. Amphibian Species of the World: An Online Reference. Version 4 (17 August 2006). New York: American Museum of Natural History.

Goldman, Robert P., Sheldon I. Pollock, et al., trans. 2005-2006. Ramayana, 5 vols. New York: JJC Foundation and New York University Press.

Gould, Stephen Jay. 1989. Wonderful Life: The Burgess Shale and the Nature of History. New York. W. W. Norton.

Guenther, Herbert V. 1972. Buddhist Philosophy in Theory and Practice. Baltimore: Penguin.

Hess, H. H. 1962. "History of Ocean Basins.” Petrologic Studies: A Volume to Honor A. F. Buddington. eds. A. E. J. Engle et al. Geologic Society of America: 599-620.

Ians. 2017. "Bengaluru Based Geologist Discoveries 2,00o Million Years Old Microfossils." The New Indian Express, 23 November.

Jagoutz, Oliver et al. 2015. "Anomalously Fast Convergence of India and Eurasia caused by Double Subduction." Nature Geo- 
science 8, no. 6: 475-478.

Kenoyer, J. M. 1998. Ancient Cities of the Indus Valley Civilization. Karachi: Oxford University Press.

Knoll, A. H., and E. S. Barghoorn. 1977. "Archean Microfossils Showing Cell Division from the Swaziland System of South Africa." Science 198: 396-398.

Krishnan, M. S. 1953. The Structural and Tectonic History of India. Memoirs of the Geological Survey of India, No. 81.

___. 1967. “Tectonics of India.” Bulletin of the Indian Geophysical Union, 3: 1-51.

-_- 1982. Geology of India and Burma. $6^{\text {th }}$ edition. New Delhi: CBS Publishers.

Kühl, Gabriele, et al. 2012. Visions of a Vanished World: The Extraordinary Fossils of the Hunsrück Slate. New Haven: Yale University Press.

Kumar, Prakash, et al. 2007. "The Rapid Drift of the Indian Tectonic Plate." Nature 449 no. 7164: 894897.

Lee, R. B., and I. DeVore, eds. 1968. Man the Hunter. Chicago: Aldine.

Leis, Bob, and Bruce L. Stinchcomb. 2015. Stromatolites: Ancient, Beautiful, and Earth-Altering. Atglen, PA: Schiffer Publishing.

Levi-Setti, Riccardo. 2014. The Trilobite Book. Chicago: University of Chicago Press.

Lopuchin, A. S. and S. Sambe Gowda. 1983. "Microbiota from the Early Precambrian of South India: Evolutionary Significance and Perspectives of Biostratigraphy." Proceedings of the Indian Academy of Science (Plant Science) 92. No. 4 (August): 335-355.

Lopuchin A. S. and V. M. Moralev. 1973. "Alga-like Microfossils in the Archean Rocks of South India," Geology Explorations 22: 185187.

Maisels, Charles Keith. 1990. The Emergence of Civilization: From Hunting and Gathering to Agriculture, Cities, and the State in the Near East. London: Routledge.

Mathur, U. B. 2004. "Rajasaurus narmadensis." Current Science 86, no. 6: 761-762.
Metspalu, M, et al. 2004. "Most of the Extant mtDNA Boundaries in South and Southwest Asia were Likely Shaped During the Initial Settlement of Eurasia by Anatomically Modern Humans." (Abstract) BMC Genetics, 5 (August): 26.

Misra, V. N. 2001. "Prehistoric Human Colonization of India." Journal of Biosciences 26, no.4: 491-531.

Mora, Camilo, et al. 2011. "How Many Species Are There on Earth and in the Ocean?" PLOS, August 23.

Open access. https://

doi.org/10.1371/

journal.pbio.1001127.

Morris, Conway, and H. B. Whittington. 1989. "The Animals of the Burgess Shale." Scientific American 240 (January): 122-133.

Oppenheimer, Stephen. 2003. Out of Eden: The Peopling of the World. London: Constable E Robinson.

Organ, Troy Wilson. 1974. Hinduism: Its Historical Development. New York: Barron's Educational Series.

Pant, D. D. and R. Pant. 1987. "Some Glossopteris Leaves from Indian Triassic Beds." Palaeontographica. 205B: 165-178.

Parpola, Asko. 2015. The Roots of Hinduism. The Early Arians and the Indus Civilization. New York: Oxford University Press.

Powell, C. et al. 1988. "Pre-Breakup Continental Extension in East Gondwanaland and the Early Opening of the Eastern Indian Ocean." Tectonophysics 155 (1-4): 261-283.

Possehi, Gregory 1. 1997. "The Transformation of the Indus Civilization." Journal of World Prehistory 11, no. 4: 425-472.

Ptolemy, Claudius. 1991. The Geography. Trans. and Ed. Edward Luther Stevenson. New York: Dover Publications.

Raghavan, J., ed. 1980. The Ramayana Tradition in Asia: Papers Presented at the International Seminar on the Ramayana Tradition in Asia, New Delhi, December, 1975. New Deli: Sahitya Akademi.

Rao, B. Rama. 1945. The Charnockite Rocks of Mysore, Southern India. Bulletin 18, Mysore Geological
Department, Bangalore. Published online by Cambridge University Press, 2009.

Reich, David, et al. 2009.

"Reconstructing Indian Population History." Nature 461, no. 7263: 489-494,

Rogers, J. J. 1993. "India and Ur." Geological Society of India 42 (3): 217222.

- 1996. "A History of Continents in the Past Three Billion Years." Journal of Geology 104: 91-107.

Ruhlen, Merritt. 1994. The Origin of Language: Tracing the Evolution of the Mother Tongue. New York: John Wiley.

Sardet, Christian. 2015. Plankton: Wonders of the Drifting World. Chicago: University of Chicago Press.

Schopf, J. William, and K. N. Prasad. 1978. "Microfossils in Collenialike Stromatolites from the Proterozoic Vempalle Formation of the Cuddapah Basin, India." Precambrian Research. 6, nos. 3-4 (May): 347-366.

Sereno, P.C., et al. 1993. "Primitive Dinosaur Skeleton from Argentina and the Early Evolution of the Dinosauria." Nature 361, 64-66.

Sharma, Mukund. 2008. "Stromatolites Studies in India: An Overview." The Palaeobotanist 57: 63-67.

Smith, Huston. 1979. India and the Infinite: The Soul of a People (DVD). Director: Elda Hartley. Hartley Film Foundation.

Sullivan, Walter. 1974. Continents in Motion: The New Earth Debates. New York: McGraw-Hill.

Takeuchi, H., S. Uyeda, and H. Kanamori. 1970. Debate about the Earth: Approach to Geophysics through Analysis of Continental Drift. Revised edition. Trans. Keiko Kanamori. San Francisco: Freeman, Cooper \& Co.

Thewissen, J. G. M. et al. 2001. "Eocene Mammal Faunas from Northern Indo-Pakistan." Journal of Vertebrate Paleontology 21 (2): 347-66.

Walter, M. R. 1983. "Archean Stromatolites: Evidence of the Earth's Earliest Benthos.” In J. W. Schopf, ed. Earth's Earliest Biosphere: Its Origin and Evolution. Princeton: Princeton University Press, 187- 
213.

Van Hinsbergen, D. 2012. "Greater India Basin Hypothesis and a Two-stage Cenozoic Collision between India and Asia." Proceedings of the National Academy of Sciences 109 (20): 7659-7664.

Walshe, Maurice, and Sumedho Thera. 1995. The Long Discourses of the Buddha: A Translation of the Digha Nikaya (The Teachings of the Buddha), $2^{\text {nd }}$ edition. Somerville, MA: Wisdom Publications.

Wegener, Alfred. 1915. The Origin of Continents and Oceans. New York: Dover Publications.

Wessman, Fred, and Jaelyn J. Eberle.
1999. Trilobites from the Fred Wessman Collection. Houston: Houston Museum of Natural Science.

White, Mary E., 1990. The Flowering of Gondwana. Princeton, NJ: Princeton University Press.

Wilson, J. A. et al. 2003. "A New Abelisaurid (Dinosauria, Theropoda) from the Lameta Formation (Cretaceous, Maastrichtian) of India." Contributions from the Museum of Paleontology University of Michigan 31 (1): 1-42.

Wood, Barry. 2017. "From Atoms to Atman: The Grand Narrative and the Emergence of Spirit." Our
Place in the Cosmos: Big History and Universal Consciousness. In The International Journal for Transformation of Consciousness 3, no. 1 (Jan-July): 246-26o. . 2019a. "Petrotemporality at Siccar Point: James Hutton's Discovery of Deep Time." Time's Urgency. Ed. Carlos Montemayor. Leiden: Brill, 2019. 57-78.

__— 2019b. "Beachcombing and Coastal Settlement: The Journey from South Africa to Patagonia." Journal of Big History 3, no. 4. 1946. 